Türk Coğrafya Dergisi
Sayı 63: 57-69, istanbul
http://www.tcd.org.tr

\title{
Türk Coğrafya Kurumu Faaliyetleri
}

\section{(1 Ocak - 31 Aralık 2014)}

\section{T. Ahmet ERTEK}

Türk Coğrafya Kurumu Başkanı

19 Ocak 2013 Cumartesi günü Türk Coğrafya Kurumu (TCK) Olağan Genel Kurulu'nda seçilen idari kurulları 2014 yılında da faaliyetlerini sürdürmüşlerdir:

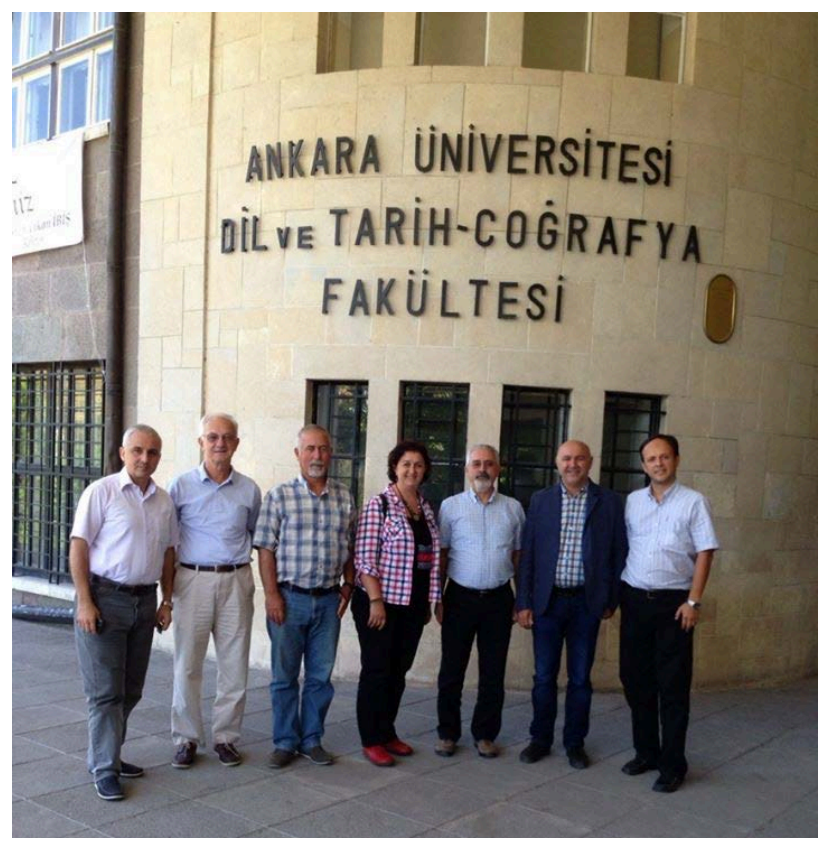

Türk Coğrafya Kurumu Yönetim Kurulu Üyeleri, bir Yönetim Kurulu Toplantısı sonrasında. Soldan itibaren: Barbaros GÖNENÇGiL, Faruk ÖZBAKAN, ìssan çiçEK, Fügen DEDE, Ahmet ERTEK, İhsan BULUT, Mesut SÜZER (Ankara, 7 Eylül 2013).

\section{YÖNETIM KURULU (ASIL ÜYELER)}

1-Y.Doç. Dr. T.Ahmet ERTEK (Başkan)

2- Prof. Dr. İhsan ÇiçEK (Başkan Yrd.)

3- Fügen DEDE (Başkan Yrd.)

4- Prof. Dr. Barbaros GÖNENÇGIL (Genel Sekreter)

5- Faruk ÖZBAKAN (Muhasip Üye)

6- Prof.Dr. İhsan BULUT (Üye)

7- Mesut SÜZER (Üye)

\section{YÖNETIM KURULU (YEDEK ÜYELER)}

1- Prof.Dr. Deniz EKINCI

2- Doç.Dr. Vedat ÇALIŞKAN

3- Prof. Dr. Hakan YiĞiTBAŞıOĞLU

4- Prof. Dr. Mustafa MUTLUER
5- Prof. Dr. Recep EFE

6- Doç. Dr. Meryem HAYIR

7- Y.Doç.Dr. Cihan BAYRAKDAR

DENETIM KURULU (ASIL ÜYELER)

1- Kemal AKALIN (Başkan)

2- Av./Coğrafyacı Cem YILDIZ (Üye)

3- Eylem ACAR (Üye)

\section{DENETIM KURULU (YEDEK ÜYELER)}

1- Y.Doç. Dr. Musa ULUDAĞ

2- Doç. Dr. Evren ERGINAL

3- Araş.Gör. Belgin SOL

HAYSIYET DIVANI (ASIL ÜYELER)

1- Prof. Dr. Illhan KAYAN

2- Prof. Dr. İbrahim ATALAY

3- Prof. Dr. Tuncer DEMIR

4- Prof. Dr. Saliha KODAY

5- Prof. Dr. Füsun BAYKAL

HAYSIYET DIVANI (YEDEK ÜYELER)

1- Prof. Dr. Emrullah GÜNEY

2- Prof. Dr. Özer YILMAZ

3- Prof. Dr. Ali UZUN

4- Prof. Dr. Süheyla AKOVA

5- Prof. Dr. Telat KOÇ

NOT: Haysiyet Divanı Üyemiz (yedek) ve Afyon Kocatepe Üniversitesi Coğrafya Bölümü Öğretim Üyesi Prof.Dr. Özer YILMAZ 29.12.2013 günü hakkın rahmetine kavuşmuştur. Coğrafya Ailesine başsağlığı dileriz.

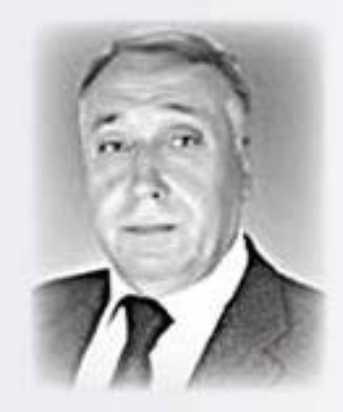

Prof.Dr. Özer YILMAZ

(1956-2013) 
2014 yılı için Türk Coğrafya Dergisi Yazı Kurulu'na Yönetim Kurulu Üyelerimiz tarafından aşağıdaki üyelerimiz yeniden seçilmişlerdir:

Doç.Dr. Hasan ÖZDEMiR (Baş-editör)

Prof.Dr. Barbaros GÖNENÇGiL (üye)

Prof.Dr. İhsan çiçEK (üye)

Prof.Dr. İhsan BULUT (üye)

Y.Doç.Dr. Ahmet ERTEK (üye)

- 3 Mart 2014 günü üyelerimizden Araş.Gör. Belgin SOL ve Araş.Gör. Mehmet Emin CiHANGiR'in denetiminde Laleli'deki dernek merkezimizde kurumumuza ait yayınlanmış dergi ve kitapların sayımı yapılarak dökümü çıkarılmış ve TCK Sekreterliğine bir rapor teslim edilmiştir.

- "22 Mart Dünya Su Günü"nde yeşil bayrak sahibi bir eko okul olan FMV Özel Ayazağa Işık Ortaokulu'nda, toplum hayatı açısından büyük öneme sahip olan ormanların zengin biyolojik çeşitliliğine dikkat çekmek ve öğrencilerin okulda öğrendikleri bilgileri kullanabilmelerini sağlamak amacıyla "Su" temalı Eko-Okul çalışmaları kapsamında "İstanbul ili Ortaokullar Arası Sosyal Bilimler Proje Yarışması" düzenlenmiştir. 17 Okul katılmıştır. Kurumumuzun jüri olarak davet edildiği ve ana teması "Ağaçların Gizemli Dili" olarak belirlenen proje yarışmasında konuk okulların proje sunumları 22 Mart 2014 Cumartesi günü öğleden önce izlenmiştir. Türk Coğrafya Kurumu Yönetim Kurulu Üyelerimizden; kurum Başkanı ve İstanbul Üniversitesi Edebiyat Fakültesi Coğrafya Bölümü Öğretim Üyesi Y.Doç.Dr. Ahmet ERTEK ile kurum Genel Sekreteri ve İstanbul Üniversitesi Edebiyat Fakültesi Coğrafya Bölümü Fiziki Coğrafya Anabilim Dalı Başkanı ve Öğretim Üyesi Prof.Dr. Barbaros GÖNENÇGiL hocaların jüri üyeliklerinde projeler değerlendirilmiş ve ödül törenine geçilmiştir. Jüri üyeleri tarafından açıklanan proje yarışmasının ödül kazanan okulları, ekibi, danışman öğretmenleri ve proje başlıkları şöyledir:

\section{1. Özel Evrim Okulları: "Ağacın Ruhu”}

Öğrenciler: Eren Oneil ŞiMŞEK, Tibet YILMAZER, Deniz AKAN

Danışman Öğretmen: Meryem AYDIN

2. FMV Özel Erenköy Işık Ortaokulu: "Halkalardan Bilinmeyene Yolculuk"

Öğrenciler: Ceren Naz DENGIZ, Kaan DOST, Yasemin KOCASAKAL

Danışman Öğretmen: Berrak ERTOSUN-Yelda BABA

3. Özel Feriköy Ermeni Ortaokulu: "Her Insana Bir Tohum" Öğrenciler: Meline TEMELCi, Liza OLGAR, Ani KENAN Danışman Öğretmenler: Mehmet Şah ERINCIK

Mansiyon Ödülü Alan Okullar:

- TED İstanbul Koleji Vakfı Özel Ortaokulu: "Yeşil Soluk"

- Özel Çevre Ortaokulu: "Ağaçla Barış" https://www.facebook.com/isikilkogretimayazaga
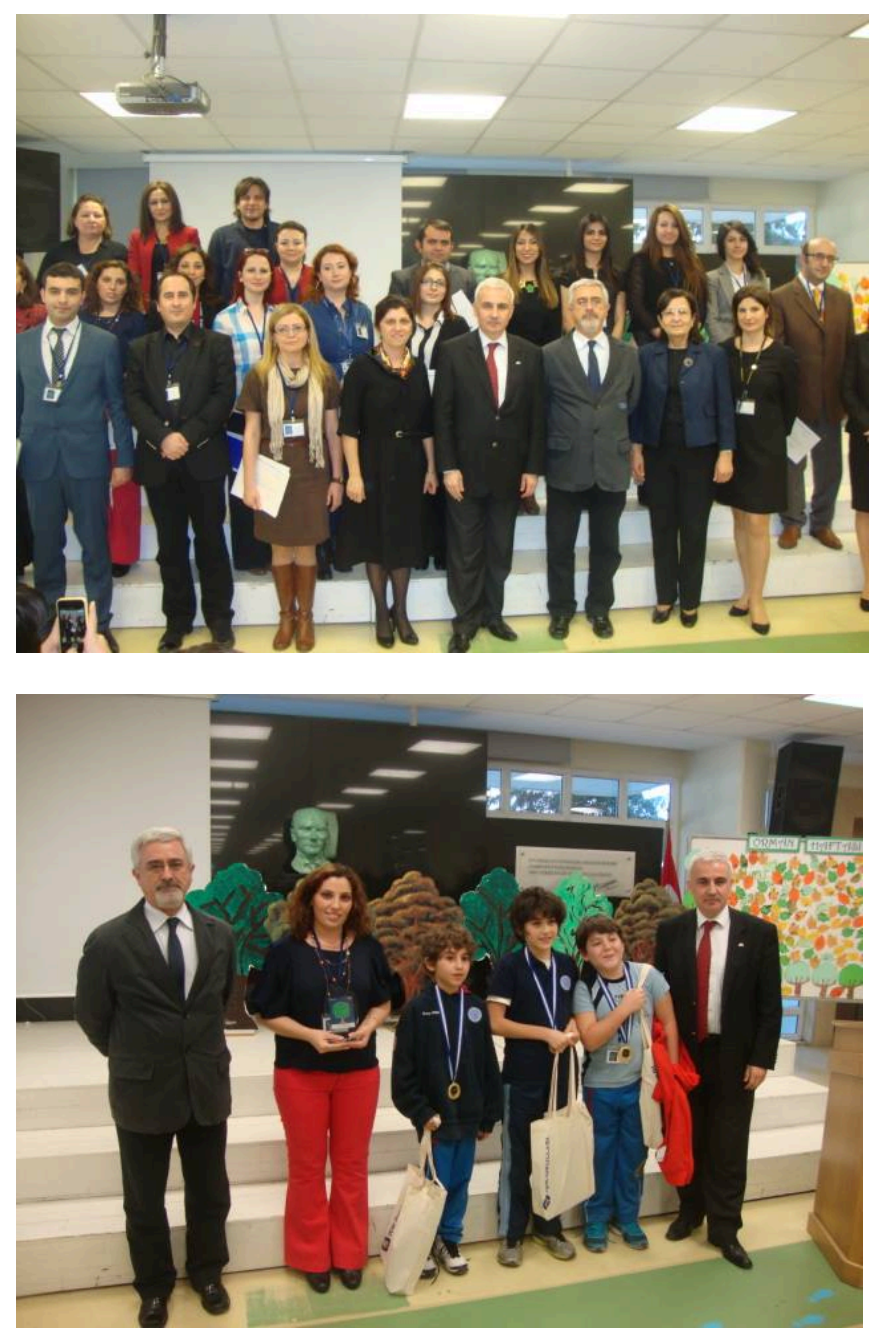

Feyziye Mektepleri Vakfı Özel Ayazağa-Işık Ortaokulu İstanbul ili Ortaokullar Arası 2. Sosyal Bilimler Proje Yarışması Ödül Töreni danışman coğrafya ve sosyal bilgiler öğretmenleri (üstte) ve proje yarışması birincisi olan Özel Evrim Okulları takımı TCK jüri üyeleriyle (altta)(22.3.2014).

Türk Coğrafya Kurumu «7.Liseler Arası Ulusal Proje/Kısa Belgesel/Animasyon Yarışması» ANA TEMA: TEKNOLOJi ve MEKAN’nın ödül töreni, Coğrafya Öğretmenleri olan; TCK Yönetim Kurulu Üyemiz Mesut SÜZER ve üyemiz Çağdaş YÜKSEL denetiminde 24 Mayıs 2014 Cumartesi günü Adapazarı-ENKA Koleji'nde gerçekleştirilmiştir. Dereceye giren öğrenci, okul ve danışman öğretmen isimleri şöyledir: 
1. Kuleli Askeri Lisesi / KÄIĞIN SON ÇIRPINIŞLARI: ISTANBUL BOĞAZI VE YANIK SAYVANT İstanbul BALIKÇILIK UYGULAMASI 2. Salihli Bilim ve SanatTURISTiK ALANLARIN YÖRE HALKINA EKONOMiK ETKILERININ Musa ÇOBAN
Merkezi / Manisa ARAŞTIRILMASINA BIR ÖRNEK: SART KASABASI (SARDES) 3. Salihli Bilim ve SanatSALIHLi ŞEHIR MERKEZi YERLEŞiMinde ROMAN MAHALLESi VE Musa ÇOBAN
Merkezi / Manisa KENTSEL DÖNÜŞÜMÜ

\section{Derece Okul Adı}

Kısa Belgesel / Animasyon Adı

1. Sancaktepe Okyanus Anadolu Lisesi SAPANCA GÖLÜ VE BiZ

2. İstek Özel Belde Lisesi

3. İstek Özel Belde Lisesi
GÖç

MINECRAFT İLE 3 ÇAĞ

\section{Danışman Öğretmen}

İrfan AKAR

Güldem ÖZTÜRK

Güldem ÖZTÜRK

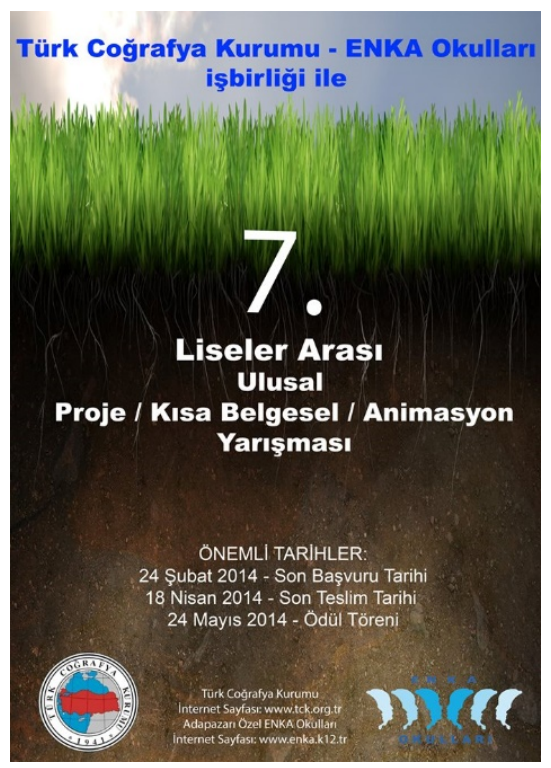

7. Liseler Arası Proje Yarışması afişi.

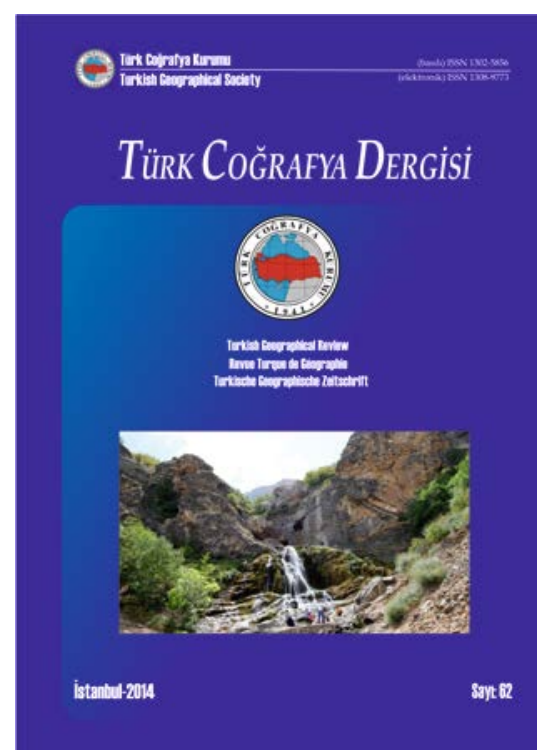

Türk Coğrafya Dergisi Sayı: 62 kapağı (2014).
- 2014 yılı Haziran ayı sonu itibariyle; kurumumuz periyodik yayın organı olan Türk Coğrafya Dergisinin 62. Sayısı internet ortamında Doç. Dr. Hasan ÖZDEMIR'in Başeditörlüğünde yayınlanmıştır (http://www.tcd.org.tr/index.php/tcd).

- 11.Uluslararası Coğrafya Olimpiyatları seçmeleri İstanbul'daki İstinye-ENKA Kolejinin salon ve sınıflarında Olimpiyat Kafilesi Başkanı ve kurumumuz Genel Sekreteri Prof.Dr. Barbaros GÖNENÇGiL ile Yönetim Kurulu Üyemiz ve Coğrafya Öğretmeni Mesut SÜZER hocaların denetiminde, önceden belirlenen jüri üyeleri önünde İngilizce yazılı (27.4.2014) ve İngilizce mülakat (11.05.2014) olarak sınavları yapılarak finale kalıp, Polonya'nın Krakow kentinde Ağustos 2014'te yapılan liselerarası "11.Uluslararası Coğrafya Olimpiyatları"na katılmayı başaran öğrencilerin isimleri şöyledir:

\begin{tabular}{lll} 
SIRA & Adı Soyadı & OKULU \\
\hline 1 & Arda Tırnaklı & HISAR OKULLARı \\
2 & Cesur Kılıç & GALATASARAY LiSESi \\
3 & Merve Akyol & GALATASARAY LiSESi \\
4 & Sarper Ege Güvenç & KABATAŞ ERKEK LiSESi
\end{tabular}




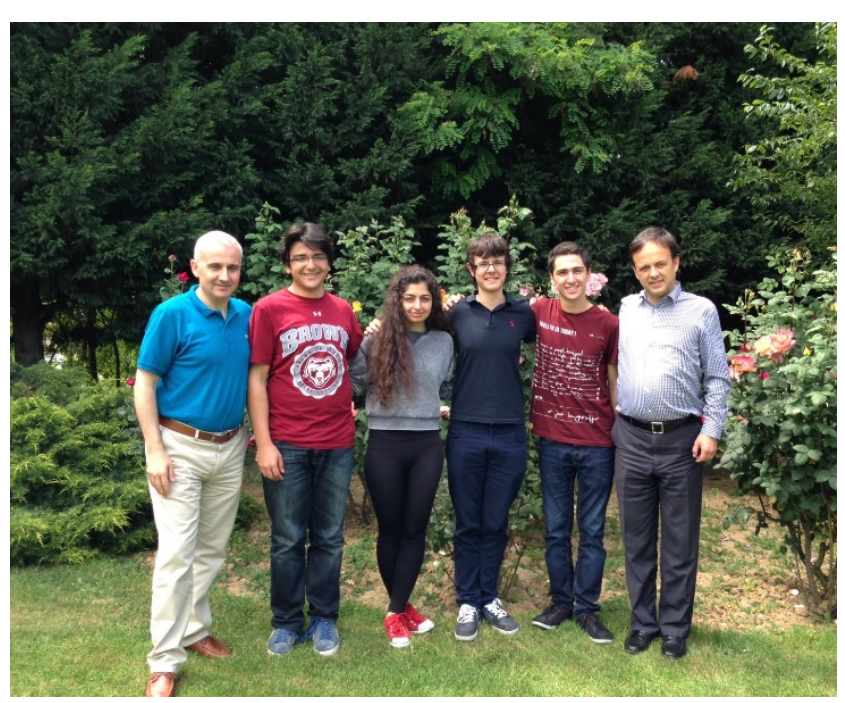

IGU-2014 Krakow'da yapılan “11. Uluslararası Coğrafya Olimpiyatları kafilesi (soldan itibaren): Prof.Dr. Barbaros Gönençgil, Türk Coğrafya Olimpiyat Takımı: Arda Tırnaklı, Merve Akyol, Sarper Ege Güvenç, Cesur Kılıç ve Coğrafya Öğretmeni Mesut Süzer (İstinye-ENKA Koleji bahçesi, 28.6.2014).

- 12-18 Ağustos 2014 tarihleri arasında TCK Genel Sekreterimiz Barbaros GÖNENÇGiL ve Yönetim Kurulu Üyemiz Mesut SÜZER hocaların başkanlıklarında daha önce kurumumuz tarafından yapılan sınavlar sonucu seçilen Arda TIRNAKLI, Cesur KILIÇ, Merve AKYOL, Sarper Ege GÜVENÇ isimli liseli öğrencilerimiz, Polonya'nın Krakow kentinde yapılan liseler arası “11. Uluslararası Coğrafya Olimpiyatları"na katılarak ülkemizi temsil etmişler ve ülke tanıtımına büyük katkılar sağlamışlardır.

- 18-24 Ağustos 2014 günlerinde Polonya'nın Krakow kentinde yapılan "IGU-2014 Regional Geography Conference (Uluslararası Coğrafya Konferansı)"na kurumumuzu temsilen TCK Başkanı Ahmet ERTEK ve Genel Sekreteri Barbaros GÖNENÇGiL katılmışlardır. Konferansa katılan üniversitelerimizin bölümlerinden Polonya'ya gelen 12 öğretim üyelerimizle koordinasyon sağlamış, sunumlarına destekler verilerek izlenmiş ve IGU Yönetim Kurulu Üyeleri (IGU Başkanı Prof.Dr. Vladimir KOLOSSOV [Rusya Federasyonu] ve onur üyesi Prof.Dr. Ron ABLER [ABD]) ile IGU-2020 Istanbul "34.Uluslararası Coğrafya Kongresi" hakkında bilgi alışverişinde bulunulmuş ve özellikle IGU Genel Sekreteri Prof.Dr. Michael MEADOWS [Güney Afrika Cumhuriyeti] ile 2 saate yakın özel toplantı yapılarak, gelecekteki İstanbul IGU-2020 toplantısının alt yapı ve planlama çalışmaları hakkında görüşlerimiz ortaya konmuştur.

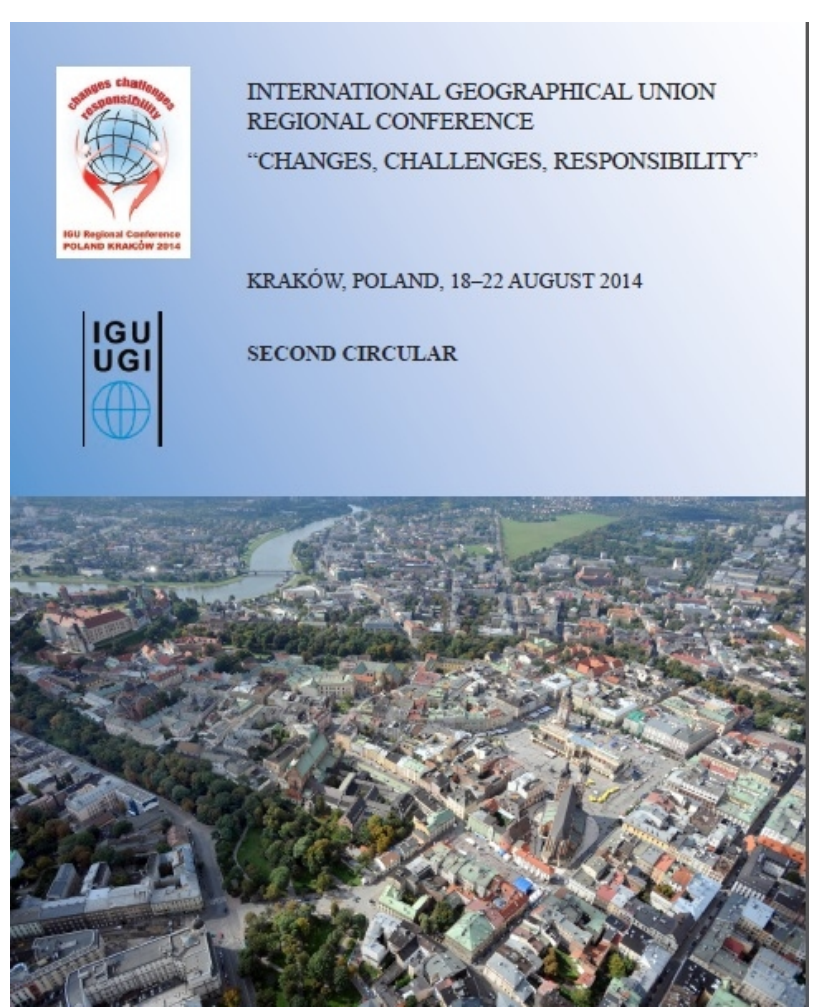

IGU-2014, KRAKOW-POLONYA (afişi).

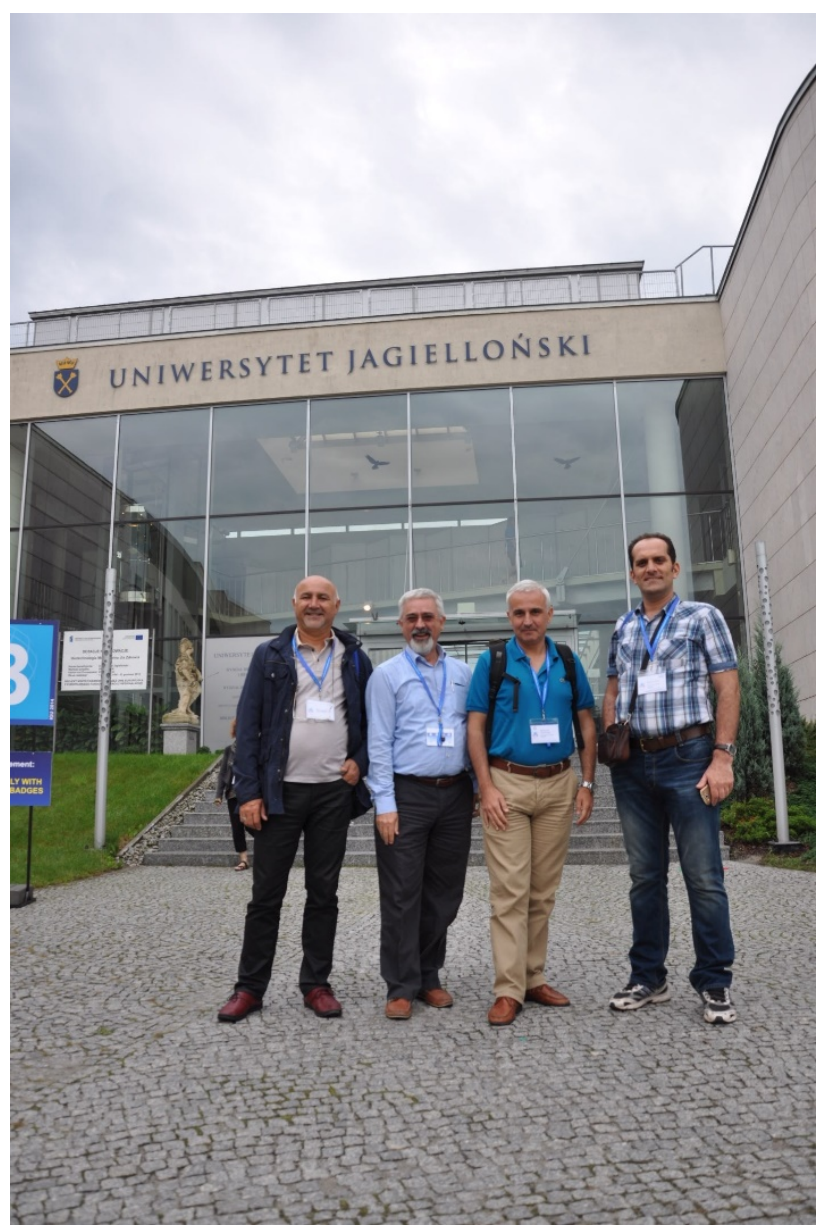

Krakow-2014 “Bölgesel Coğrafya Kongresi”ne katılan TCK Yönetim Kurulu Üyelerimiz (soldan itibaren): İhsan Bulut, Ahmet Ertek, Barbaros Gönençgil ve üyemiz Eyüp Artvinli (Krakow, 18.8.2014). 


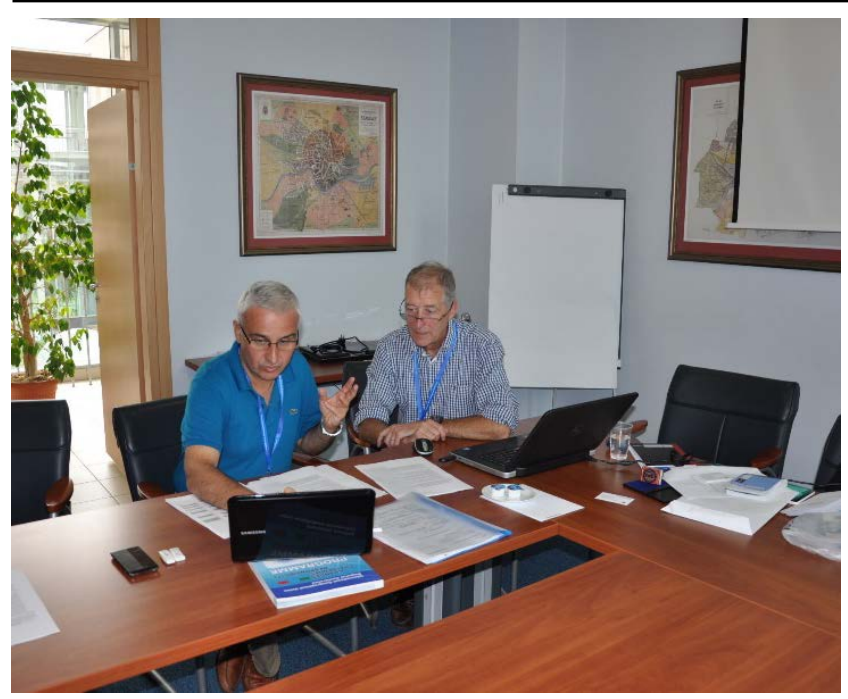

TCK Genel Sekreteri Prof.Dr. Barbaros Gönençgil ile IGU Genel Sekreteri Prof.Dr. Michael Meadows'un 2020 Ağustosunda Istanbul'da yapılacak "34.Uluslararası Coğrafya Kongresi-IGU" hakkında planlama çalışmaları yaparken (Jagiellonski Üniversitesi, Krakow-Polonya; 18.8.2014).

31 Ağustos 2014 günü Coğrafya Bölümlerimizin büyük çoğunluğunun ortak görüşleriyle Yüksek Öğretim Kurumu Başkanlığına hitaben, üniversite giriş sınavlarında ülkemiz Coğrafya Bölümlerine Eşit Ağırlık (TM-3) ile öğrenci alınması konusunda kurumumuz tarafından bir yazı yazılarak gönderilmiştir.

- 21 Ekim 2014 Salı günü Macellan'ın Ümit Burnu'nu keşfinin 500. Yılı anısına, Türk Coğrafya Kurumu Başkanı Ahmet ERTEK, Harbiye'deki TRT-i̇stanbul Radyosuna davet edilerek "Ve Ateş Bulundu" programının 14.30-15.00 arası canlı yayın konuğu olmuş; Coğrafi Keşifler, Macellan, Türkiye Coğrafyası ve kurumumuz çalışmaları hakkında kamuoyunu bilgilendirmiştir.

- 23-24 Ekim 2014 tarihleri arasında Türk Coğrafya Kurumu ile Ankara Üniversitesi Dil ve Tarih-Coğrafya Fakültesine bağlı Coğrafya Araştırmaları Merkezi (TÜCAUM)'nin birlikte gerçekleştirdiği bir davetle ülkemize gelen Uluslararası Coğrafya Birliği (IGU) Başkanı Prof. Dr. Vladimir KOLOSSOV (Rusya Federasyonu) ile IGU'ya bağlı çalışan Akdeniz Havzası Araştırmaları (COMB) Komisyonu Başkanı Prof. Dr. Maria PARADiso (italya) için düzenlenen program 21-26 Ekim günleri arasında başarıyla tamamlanmıştır:

21 Ekim günü davetliler Ankara'da karşılandıktan sonra, 22 Ekim'de günübirlik bir Kapadokya gezisi yapılmış, 23 Ekim'de ise TÜCAUM VIII. Coğrafya Sempozyumu açılış etkinliği gerçekleştirilmiştir. Prof. KOLOSSOV ve Prof. PARADisO da birer konferans vermişlerdir. Aynı gün öğleden sonra Ankara turu gerçekleştirilmiştir. 24 Ekim sabah Anıtkabir ziyaretinden sonra araçla İstanbul'a geçilmiştir. 25 Ekim'de İstanbul'da bir şehir turu yapıldıktan sonra davetlilerimiz 26 Ekim sabahı ülkelerine yolcu edilmişlerdir. Bu organizasyonun Ankara, Nevşehir ve İstanbul etapları başarı ile tamamlanmış, IGU 2020 kongresi öncesi kurumumuz ile IGU arasındaki bağlar güçlendirilmiştir. Diğer yandan VIII. Coğrafya Sempozyumu açılışında meslektaşlarımız ile IGU yöneticilerinin bir araya getirilmesi sağlanmıştır. Kentler arası tüm bu koordinasyon TCK Genel Sekreteri Prof.Dr. Barbaros GÖNENÇGiL, TCK Başkan Yardımcısı Prof.Dr. İhsan ÇiÇEK ve TÜCAUM Başkanı Prof.Dr. Ali ÖZÇAĞLAR'ın organizasyonunda gerçekleşmiştir.
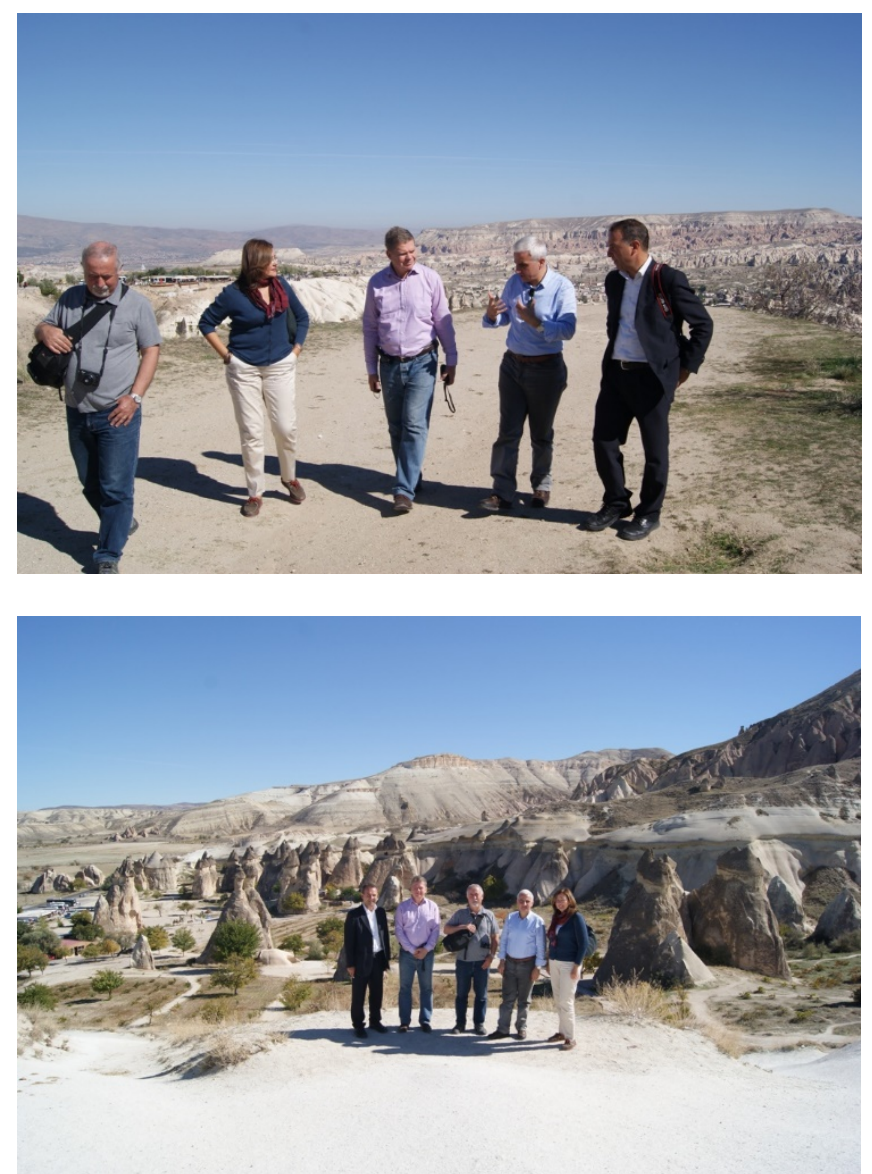

TCK Yönetim Kurulu Üyeleri; Başkan Yardımcısı Prof.Dr. İhsan Çiçek ve Genel Sekreter Prof.Dr. Barbaros Gönençgil ile üyemiz Doç.Dr. Ali Meydan Kapadokya'da; IGU Başkanı Prof.Dr. Vladimir Kolossov ve Akdeniz Havzası Komisyonu Başkanı Prof.Dr. Maria Paradiso'ya volkan topografyasıinsan ilişkileri hakkında bilgi verirken (Nevşehir, 22.10.2014). 


\section{TÜ RK CO ĞRAFYA KURUMU \\ Turkish Geographical Society}

Konu: Coğrafya Bölümlerine üniversite giriş puan türü hk.

Sayı: 23

31.08.2014

Yüksek Öğretim Kurumu Başkanlığına

ANKARA.

Ülkemizde halen üniversitelerimize bağı fakültelerde eğitim ve öğretim veren 24 'ü örgün, 16'sı ikinci öğretim olmak üzere 40 Coğrafya Bölümümüzün tamamı TS-1, yani sosyal puan türü ile üniversitelerine öğrenci almaktadır. Bu durum, 1987 yılı öncesi eşit ağırlık iken; bu yıldan itibaren 2014 üniversite giriş sınavları da dahil olmak üzere 27 yıldır sosyal puan türü şeklinde sürmektedir.

"Bilimlerin Kraliçesi” olan COĞRAFYA günümüzün modern yöntemlerine ziyadesiyle ulaşmış ve günümüzdeki çoğu akademisyen, eşit ağırlık puanı ile lisansını tamamlayıp uzmanlıklarına geçmiş kişilerden oluşmaktadır. Bunun yanısıra, yine günümüz üniversitelerinin Coğrafya müfredat programlarına ve derslerine bakıldığında istatistik, kartoğrafya, harita bilgisi, jeomorfoloji, klimatoloji, hidrografya, biyocoğrafya, toprak coğrafyası, nüfus coğrafyası, özellikle de Coğrafi Bilgi Sistemleri gibi derslerin ve uygulamalarının fizik, kimya, biyoloji bilhassa da matematik ve istatistik temeli isteyen derslerden oluştuğu herkesin malumudur. Bu nedenle de, sosyal puanla üniversiteye gelen öğrencilerin neredeyse tamamı muhakeme yeteneğinden yoksun olduklarından bu dersleri anlamakta güçlük çekmekte ve başarılı olamamaktadırlar. Oysa çift anadal ya da yan dal imkânı sağlanan arkeoloji, sosyoloji, psikoloji vb. bölümlerden eşit ağırlık puanıyla gelen ve üniversitedeki derslerimizi seçen öğrenciler "coğrafya öğrencileri”ne oranla çok daha fazla başarılı olmakta ve yüksek notlar almaktadırlar.

Camiamız, Coğrafya mezunu öğrencilerimizin günümüz ihtiyaçlarına cevap verecek donanıma sahip olmaları ve modern coğrafya eğitiminin gereklerinin yerine getirilmesi için eşit ağırlık puan türüne göre öğrenci alımının faydalı olacağına inanmaktadır.

Bu nedenle, 2015 yılında itibaren Coğrafya Bölümlerimize üniversite girişte eşit ağırlık (TM-3) puan türü ile öğrenci alınması için gereğini saygılarımla arz ederim.

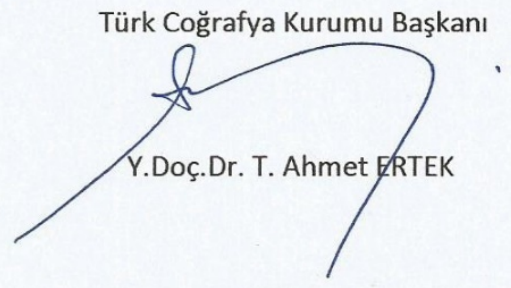

Büyükresit Paşa Cad. No: 44 Laleli, iSTANBUL/TÜRKiYE.

(00 90 212) 4555700 / 15767 - 15756 e-mail: info@tck. org.tr

www.tck.org.tr - www.tcd.org.tr 


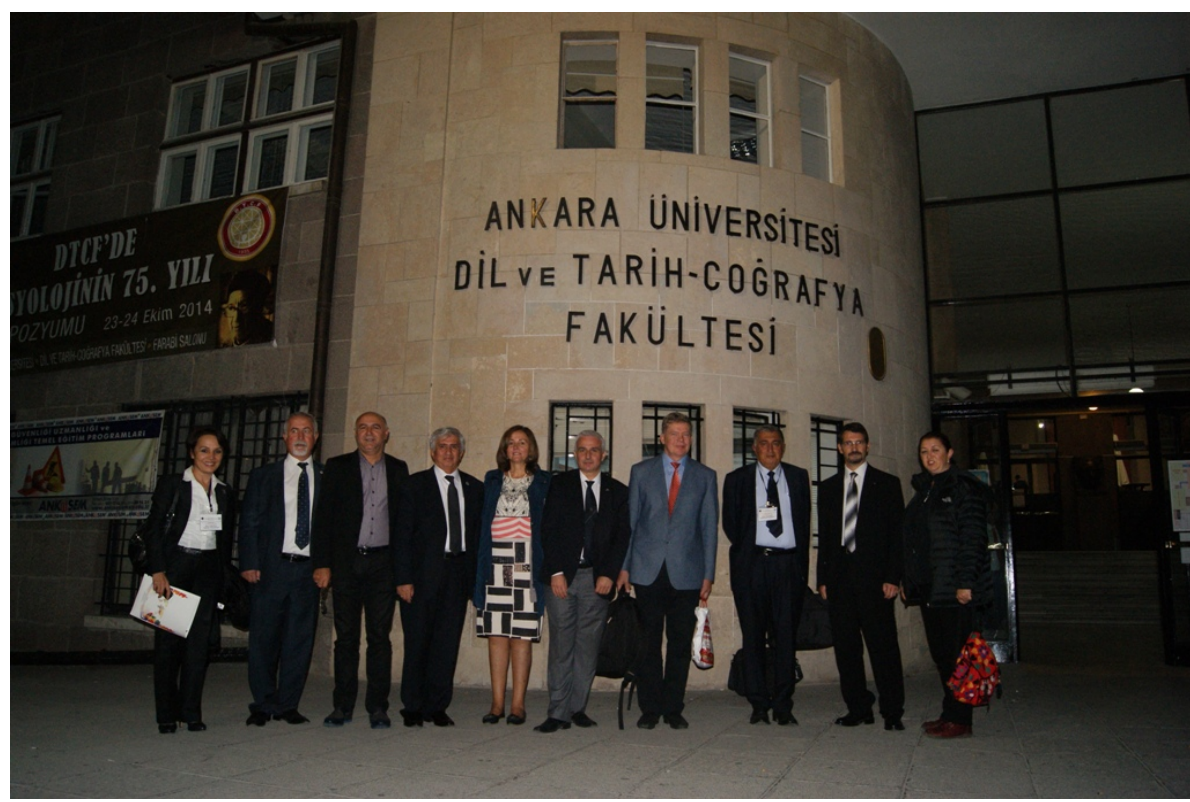

TÜCAUM-VIII. COĞRAFYA SEMPOZYUMU ilk günü bitiminden bir görüntü (Soldan itibaren: Doç.Dr. Necla Türkoğlu, Prof.Dr. İhsan Çiçek, Prof.Dr. İhsan Bulut, Prof.Dr. Ali Özçağlar, Prof.Dr. Maria Paradiso, Prof.Dr. Barbaros Gönençgil, Prof.Dr. Vladimir Kolossov, Prof.Dr. Aydın İbrahimov, Prof.Dr. Hakan Yiğitbaşığlu, Fügen Dede (Ankara , 23.10.2014).
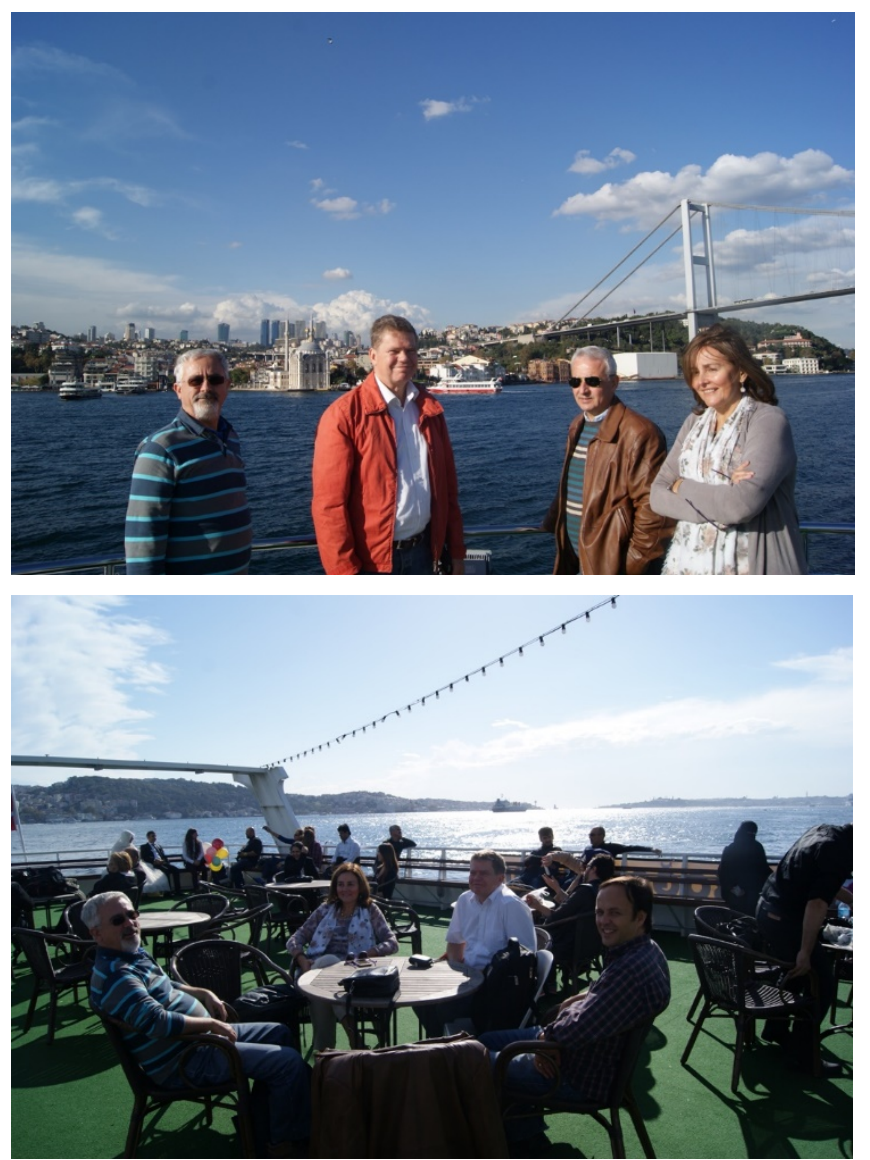

TCK Yönetim Kurulu Üyeleri; Başkan Ahmet Ertek, Genel Sekreter Prof.Dr. Barbaros Gönençgil, Yönetim kurulu Üyemiz Mesut Süzer İstanbul Boğazında IGU Başkanı Prof.Dr. Vladimir Kolossov ve IGU Akdeniz Havzası Komisyonu Başkanı Prof.Dr. Maria Paradiso ile İstanbul ve Boğaz turunda (25.10.2014).
30 Ekim - 2 Kasım 2014 tarihleri arasında Türk Coğrafya Kurumu (TCK) Başkanı Y.Doç.Dr. Ahmet ERTEK ve Genel Sekreteri Prof.Dr. Barbaros GÖNENÇGiL davet edildikleri Rusya'nın başkenti Moskova'da Rusya Coğrafya Kurumu tarafından ilk kez düzenlenen "1.Rusya Coğrafya FestivaIi"ne katılmışlardır. Gerçekleştirilen etkinliklerde akademik sunumların yanı sıra Rusya'nın farklı coğrafi bölgelerinde yaşayan halkların kültürel özellikleri düzenlenen etkinlik ve sergilerle katılımcılara tanıtılmıştır. Yüzlerce Rus vatandaşının gezdiği sergilerde yerel el ürünlerinin teşhir ve satışı dışında, yerel yaşama ait özellikler, yerel halk oyunları ve gösteriler gerçekleştirilmiştir. Bu etkinliklerin yanısıra, Türkiye ile birlikte festivale davet edilen 10 ülkenin coğrafya kurumları (Alfabetik sıra ile: Azerbaycan, Belarus, Çek Cumhuriyeti, Çin, Ermenistan, İspanya, İtalya, Kazakistan, Kırgızistan, Sırbistan) ile Rusya Coğrafya Derneği arasında bilimsel bir işbirliği anlaşması imzalanmıştır. Destekçi 4 ülke (Almanya, Finlandiya, Hindistan, İsrail) coğrafya kurumlarını temsilen birer yöneticisini göndermiştir. Türk Coğrafya Kurumu adına Yönetim Kurulu Başkanı Yrd.Doç.Dr. Ahmet ERTEK söz konusu işbirliği anlaşmasını imzalamıştır. Bu anlaşma ile iki ülke arasında akademik anlamda bilgi alışverişi ve ortak çalışmalar planlanmaktadır. Diğer ülkeler gibi; TCK Başkanı Ahmet ERTEK de kurumumuzu tanıtım amaçlı, 1 Kasım 2014 günü 20 dakikalık bir sunum da gerçekleştirmiştir(http://www.rgo.ru/en/photo/geographicalcooperation). 


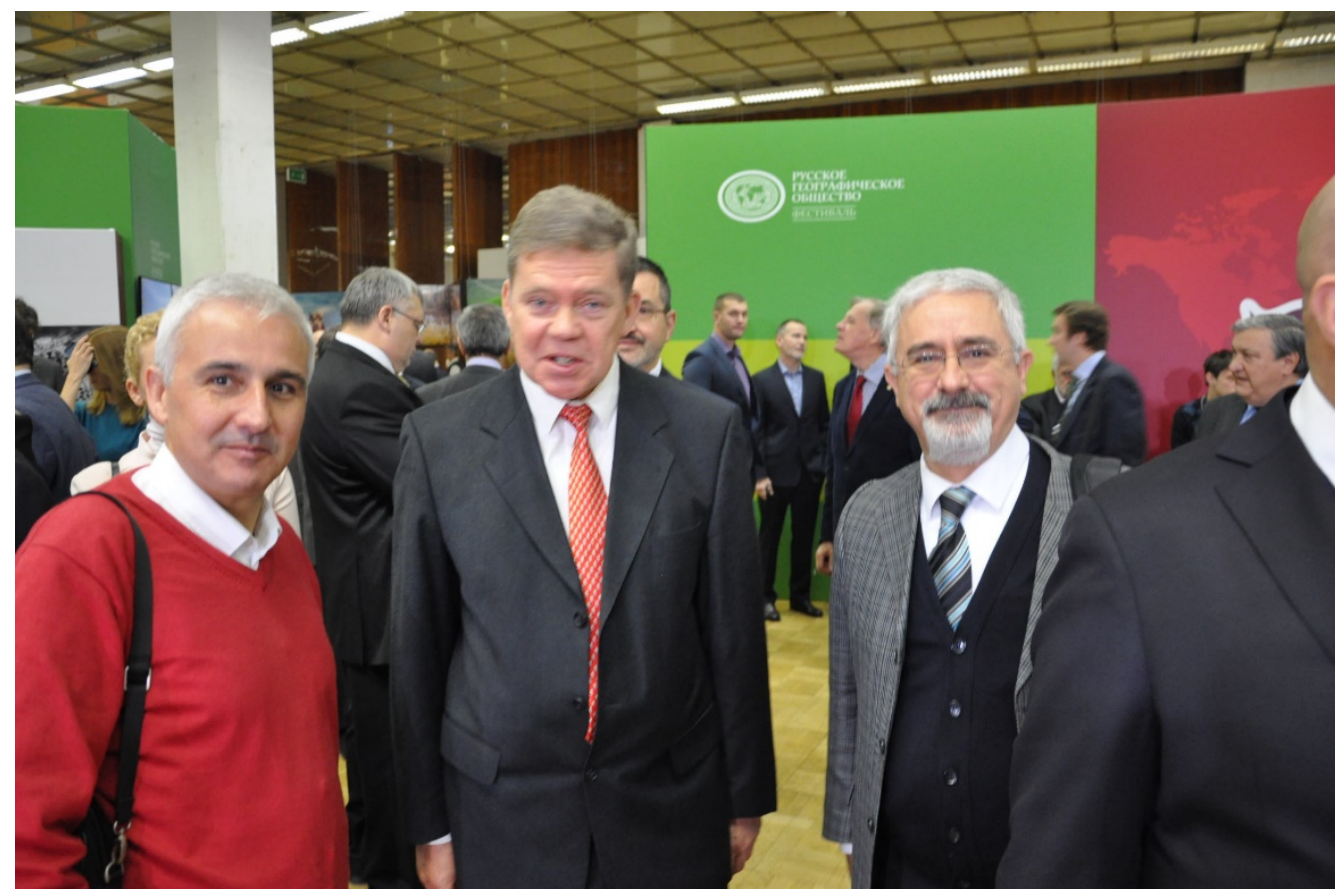

TCK Yönetim Kurulu üyeleri Gönençgil ve Ertek, Moskova'daki “1.Rusya Coğrafya Festivali”nde Rusya Federasyonu'ndan olan IGU Başkanı Prof.Dr. Vladimir Kolossov (ortadaki) ile (31.10.2014).

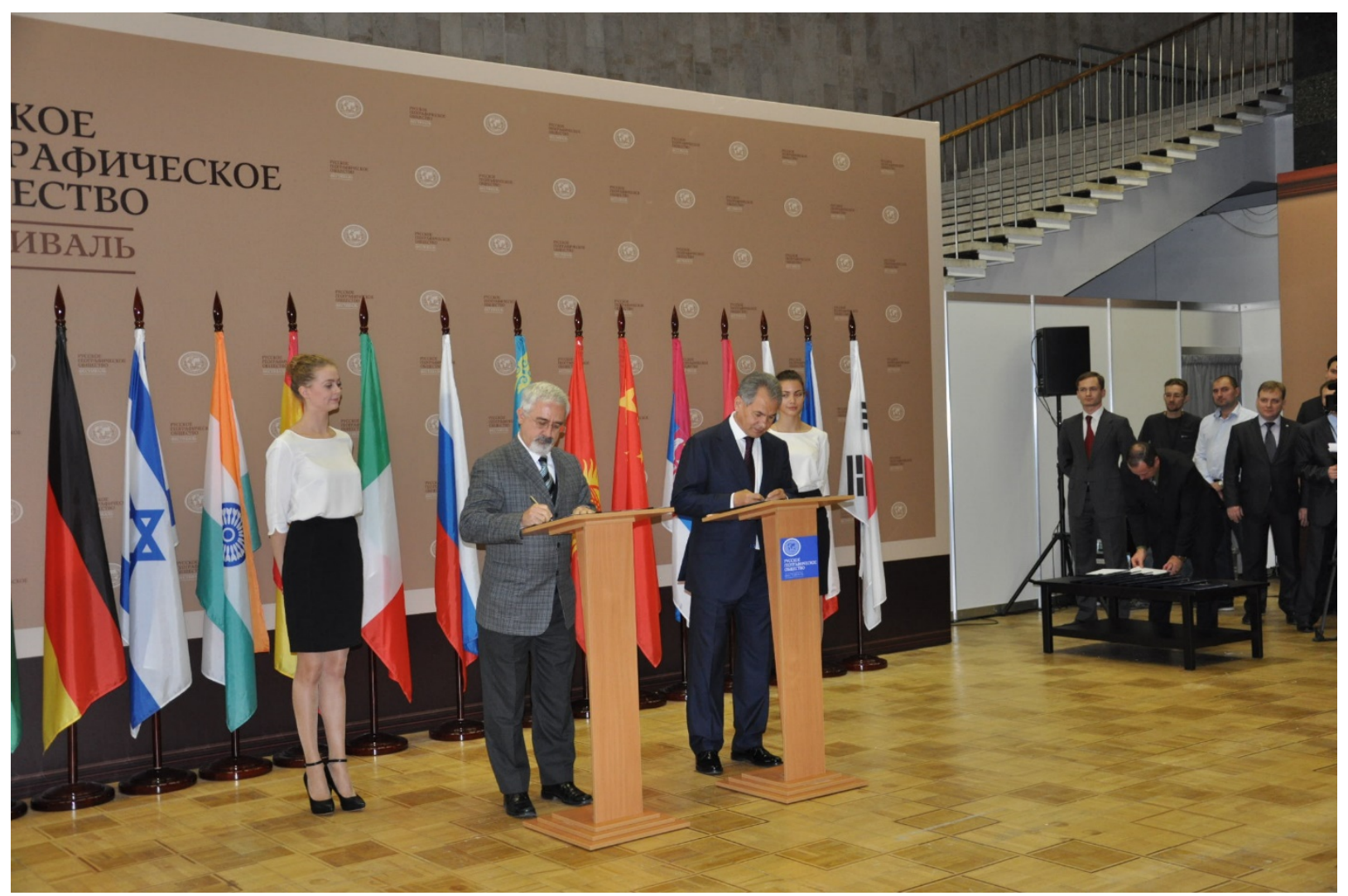

“1.Rusya Coğrafya Festivali”nde; Türk Coğrafya Kurumu Başkanı Ahmet Ertek ve Rusya Coğrafya Kurumu Başkanı ve Rusya Federasyonu Savunma Başkanı Sergei Shoigu Bilimsel Coğrafya İşbirliği Anlaşması imza töreninde (üstte) ve altta Rusya ile bilimsel işbirliğine imza koyan ülkelerin coğrafya kurumu başkanlarının topluca görünümü (altta)(Moskova, 31.10.2014) (http://www.rgo.ru/en/photo/signing-cooperation-agreements-geographical-societies-world). 

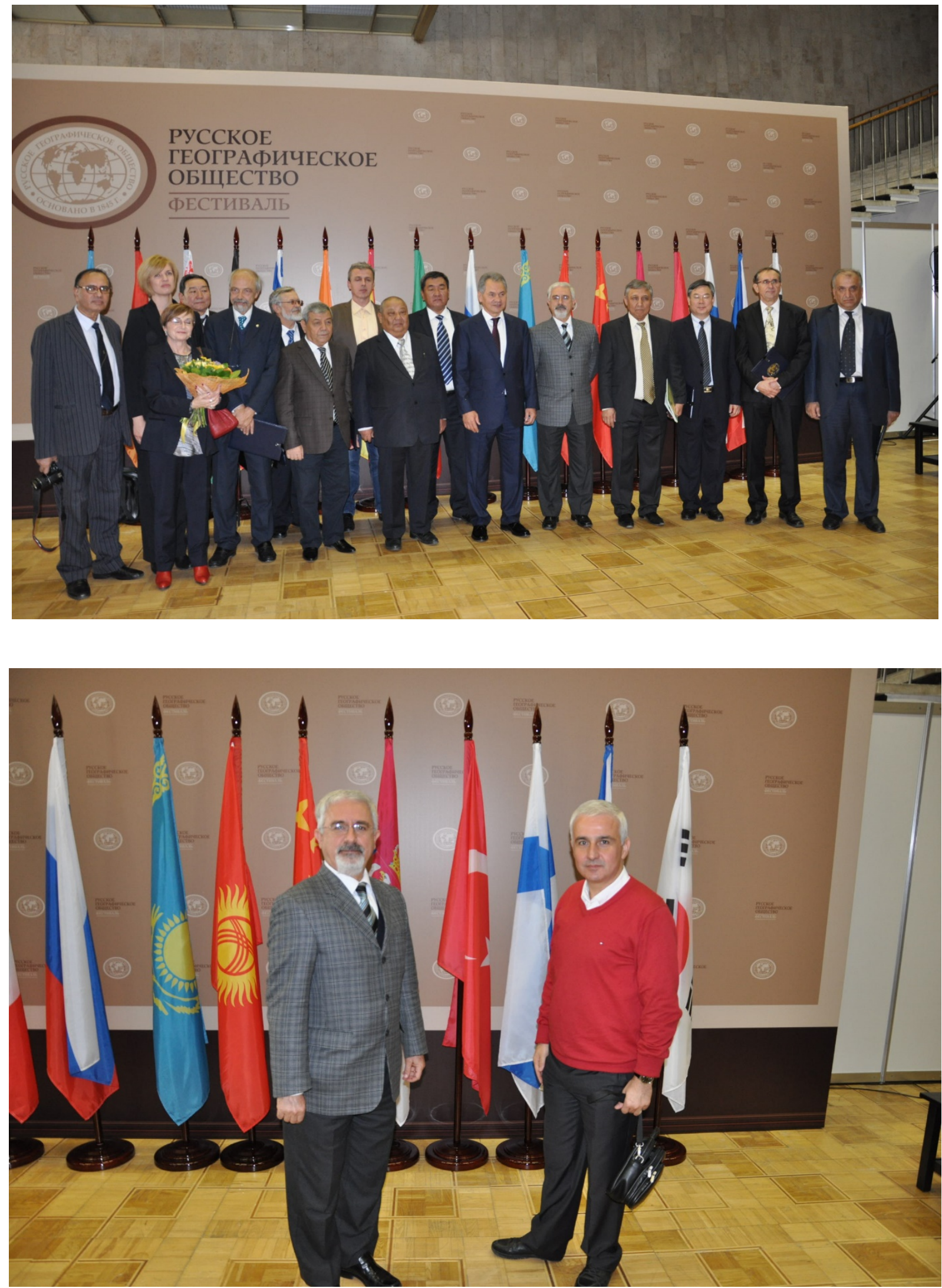

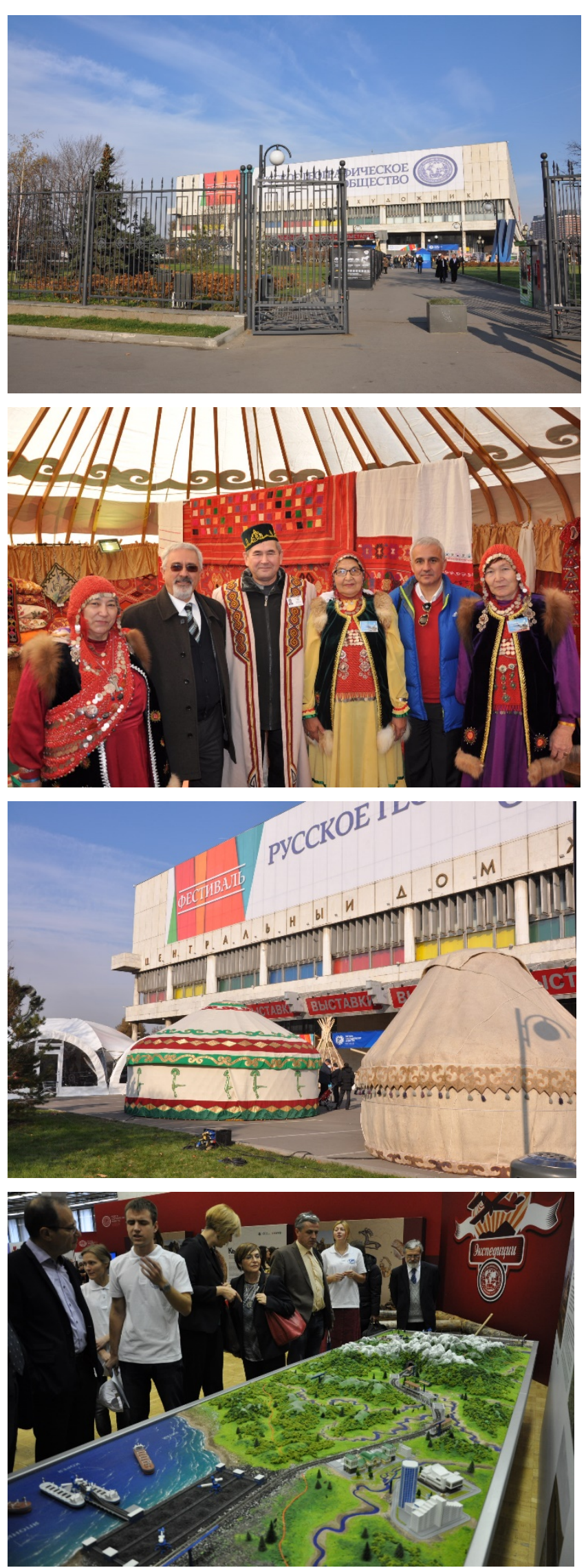

"1.Rusya Coğrafya Festivali”nden görüntüler (1 Kasım 2014, Moskova).

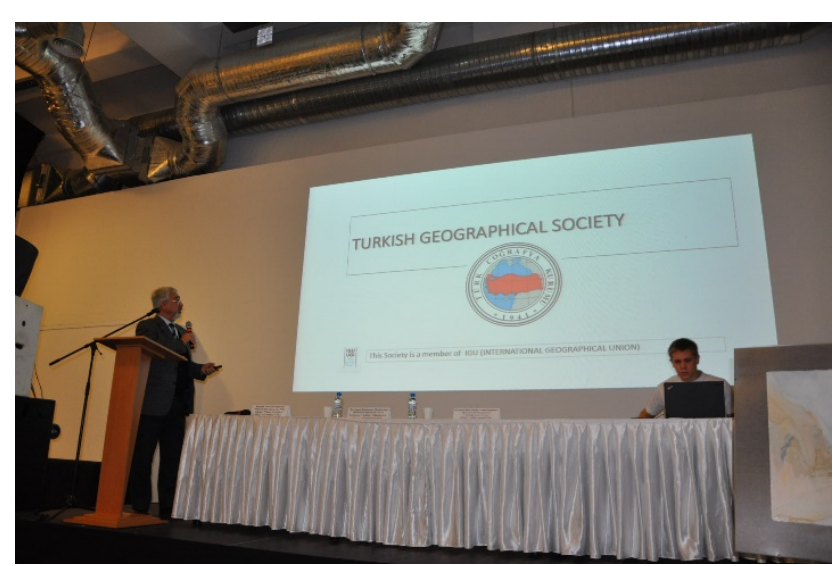

Türk Coğrafya Kurumu Başkanı Ahmet Ertek “1.Rusya Coğrafya Festivali"nde Rusya Federasyonu ile imzalanan işbirliği anlaşmasından sonra Türk Coğrafya Kurumu'nun tanıtımını sunarken (Moskova, 1.11.2014).

- Türk Coğrafya Kurumu Genel Sekreteri ve İstanbul Üniversitesi Fiziki Anabilim Dalı Başkanı Prof. Dr. Barbaros GÖNENÇGIL, Universita degli Stdi di Roma "Tor Vergata" ve Universita Europa di Roma tarafından ortaklaşa olarak 25 Kasım 2014 günü düzenlediği “Akdeniz'deki Gelişmeler” başlıklı çalıştaya davetli olarak katılmıştır. Çalıştayın tek yabancı konuşmacısı olan GÖNENÇGiL, iklim değişikliği sürecinin Türkiye'nin Akdeniz kıyılarındaki yansımaları üzerine bir konuşma yapmıştır. Ayrıca ilgili kurumlar arasında ileriye dönük olarak coğrafya alanında Akdeniz tabanlı bir işbirliğinin ilk temelleri de atılmış olup, kurumumuz organizasyonunda 2016 yılında Türkiye'de IGU Akdeniz komisyonunun bir toplantısının da Antalya'da gerçekleştirilmesi kararı alınmıştır. Yine bu çerçevede 2015 yılı Ağustos ayında Rusya'nın başkenti Moskova'da gerçekleştirilecek olan IGU Bölgesel Konferansında, ülkemiz akademisyenlerinin Akdeniz temelindeki çalışmalarını sunmaları konusunda gerekli iletişimin sağlanması da karara bağlanmıştır.

- 27.11.2014 Perşembe günü “IDME-2014” için Ankara'ya davet edilen İstanbul Üniversitesi AUZEF Acil Yardım ve Afet Yönetimi ile Coğrafya Programı Öğretim Üyeleri Jeofizik Mühendisi Prof. Dr. Ali Osman ÖNCEL ile Coğrafya Akademisyenleri ve Türk Coğrafya Kurumu Yöneticilerinden Başkan Yrd. Doç. Dr. Ahmet ERTEK, Genel Sekreter Prof. Dr. Barbaros GÖNENÇGiL ve Yönetim Kurulu Üyesi (yedek) Prof. Dr. Deniz EKINCi “3.Uluslararası Afet Yönetimi Festivali ve Konferansı-IDME 2014"e katılarak konferansa katkı vermişlerdir.

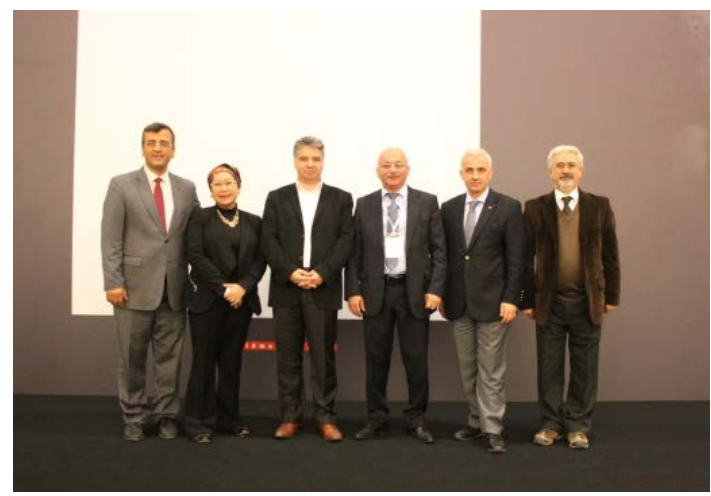


Türk Coğrafya Kurumu Faaliyetleri (1 Ocak-31 Aralık 2014)

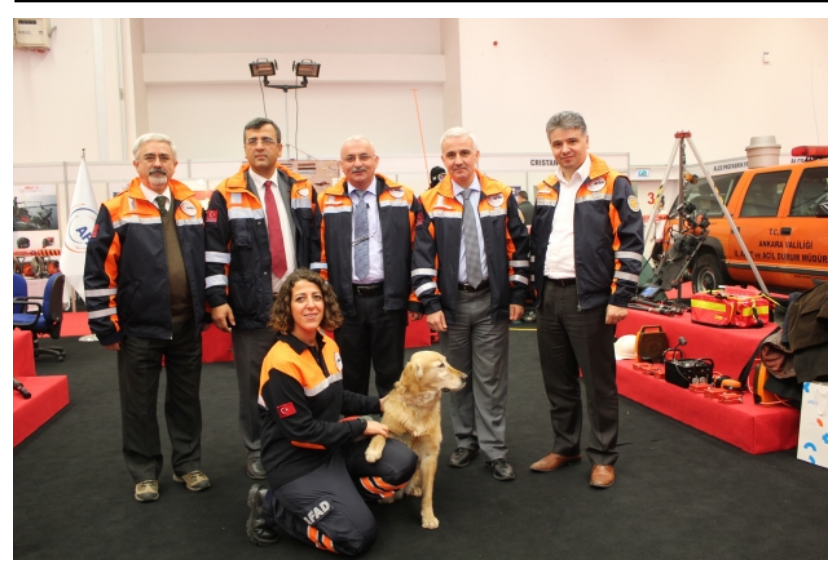

"3.Uluslararası Afet Yönetimi Festivali ve Konferansı-IDME 2014"dan görüntüler. Birleşmiş Milletler Uluslararası Afet Yönetimi Başkanı ile Ankara-AFAD Başkanı akademisyen hocalarımızla (üstte) ve İstanbul Üniversitesi ve kurumumuz yöneticisi hocalarımız Ankara-AFAD Başkanı Ömer AKBAŞ ile (altta)(Ankara-27.11.2014).

- 8-10 Aralık 2014 tarihleri arasında, 165 yıllık Rusya Coğrafya Kurumu tarafından bilim, eğitim, ekoloji, petrol aramaları, kutup araştırmaları, belgesel, fotoğrafçılık gibi 7 dalda verilen ve TCK olarak kurum başkanı Ahmet ERTEK'in Moskova'ya davet edildiği "Rusya Coğrafya Kurumu'nun "1.Kristal Pusula Ödül Töreni" 9 Aralık 2014 Salı günü yapılan bir törenle gerçekleştirilmiştir (http://www.rgo.ru/en/photo/first-award-russiangeographical-society). Ayrıca ERTEK, Moskova'daki Rusya Coğrafya Kurumu binasında yapılan işbirliği toplantısına da katılmıştır.
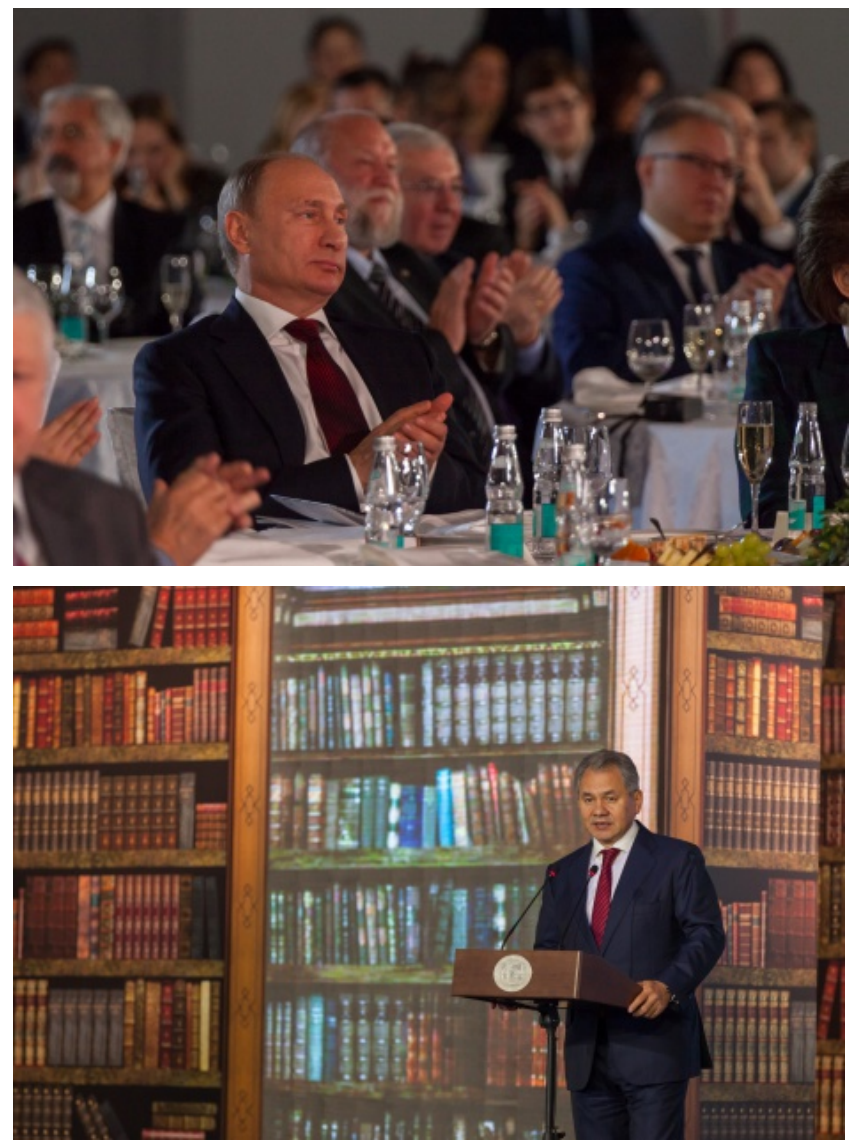

Rusya Coğrafya Kurumu'nun düzenlediği “1.Kristal Pusula Ödül Töreni"nden: Rusya Devlet Başkanı Vladimir Putin ve akademisyenler (üstte), Rusya Coğrafya Kurumu Başkanı ve Savunma Bakanı Sergei Shoigu ödül töreni açılış konuşmasını yaparken (altta)(Moskova, 9.12.2014).

- AKUT (Arama Kurtarma Derneği) tarafından davet edilen TCK Başkanı Ahmet ERTEK, "Akut Lojistik Ve Seminer Bölümü Kapasite Geliştirme Projesi" başlığı altında 20.12.2014 Cumartesi günü 10.00-13.00 arası AtaşehirRadison Blu Oteli Konferans Salonunda ülkemizin 35 Bölgesinden gelen 80 AKUT Gönüllüsüne "Bir Coğrafyacı Gözüyle Doğal Afetler (Depremler, Tsunami, Sel ve Taşkın, Heyelanlar ve Kütle Hareketleri, Volkan Patlaması)" konulu 3 saatlik bir seminer sunulmuştur.

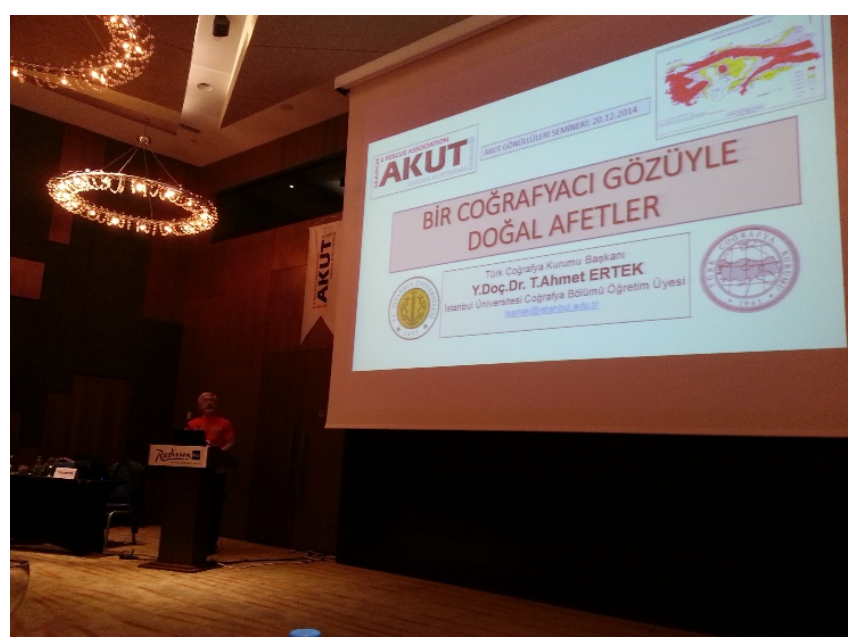

TCK Başkanı Ahmet Ertek'in AKUT Gönüllülerine verdiği seminerden (Ataşehir, 20.12.2014).

- 1939 Erzincan Depreminin 75'nci yıl dönümünde MMG, İstanbul Üniversitesi, TCK, KOERI, Erzincan Valiliği ve Erzincan Belediye Başkanlığı tarafından desteklenen İstanbul Üniversitesi İlahiyat Fakültesi Konferans Salonunda Mimar ve Mühendisler Grubu (MMG) tarafından organize edilen “75. Yılında Erzincan Depremi” konulu deprem konferansına davet edilen TCK başkanı ve i.ü.Coğrafya Bölümü Öğretim Üyesi Y.Doç.Dr. Ahmet ERTEK "Erzincan Havzasının Neotektoniği" ile TCK Yönetim Kurulu Üyesi (yedek) ve i.Ü.AUZEF Dekan Yardımcısı Prof.Dr. Deniz EKINCi "Sürdürülebilir Afet Yönetimi illkeleri" isimli birer bildiri sunmuşlardır. Konferansa ayrıca; yurt içi ve yurt dışındaki çeşitli üniversitelerden alanlarında uzman öğretim üyelerinin katıldığı konferansta "Deprem Fiziği ve Afet Vizyonu" ve "Deprem Sosyolojisi ve Afet Eğitimi" başlıklarında olmak üzere 2 oturum olarak 26 Aralık 2014 Cuma tarihinde 10.00-18.00 saatleri arasında gerçekleştirilmiştir. Illk oturumu Erzincan Belediye Başkanı Cemalettin BAŞSOY ve ikinci oturumu Erzincan Valisi Süleyman KAHRAMAN yönetmiştir. Yapılan oturumlarda konunun uzmanı 10 öğretim üyesi; 1992 Erzincan depremi ve mal ve can kaybının sebepleri ve alınacak önlemleri, sürdürülebilir afet yönetim ilkeleri, deprem sonrası yaşamda dini inancın koruyucu rolü, Türkiye'de kabuktaki sismik hız değişiminin deprem oluşumu ile ilişkisi, havza neotektoniği, depremin getirdiği 
sosyolojik değişim ve sorunlar hakkında katılımcılara detayı bilgi verilmiştir. Katılımcılara ayrıca birer Katılım Belgesi de takdim edilmiştir.

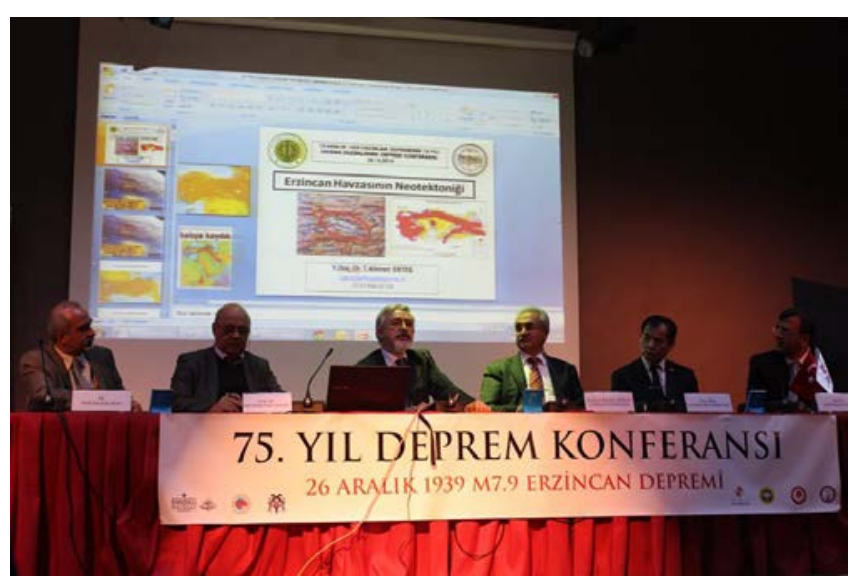

26 Aralık 1939 ERZINCAN DEPREMi'nin 75. Yılı anısına İstanbul Üniversitesinde düzenlenen konferansta TCK Başkanı Ahmet ERTEK sunumunu yaparken (Soldan itibaren: Dr. Doğan KALAFAT, Prof.Dr. İbrahim BALCIOĞLU, Y.Doç.Dr. Ahmet ERTEK, Cemalettin BAŞSOY (Erzincan Belediye Başkanı), Yük.Mimar Yoshinori MORiWAKi, Prof.Dr. Ali Osman ÖNCEL)(İstanbul, 26.12.2014).

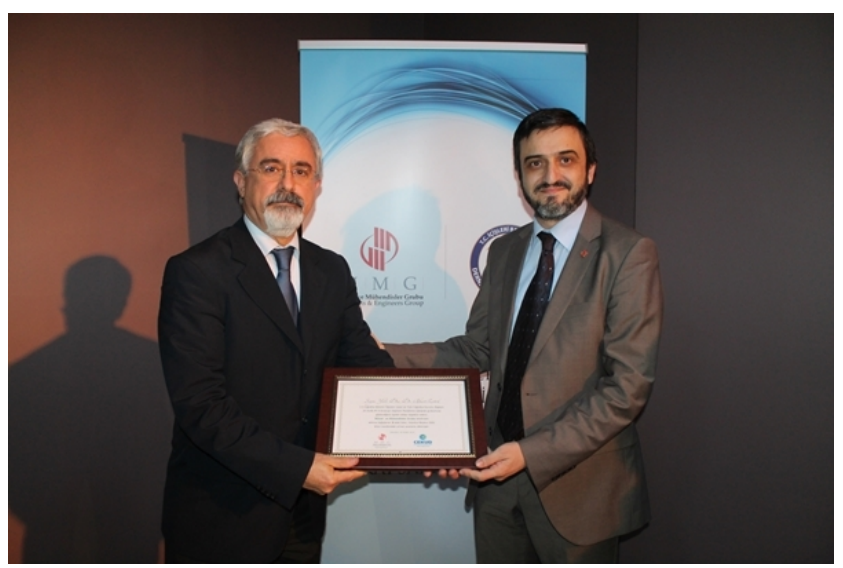

Sunumlar sonrasında TCK başkanı Ahmet ERTEK MMG Başkanı Murat ÖZDEMiR'den plaketini alırken.

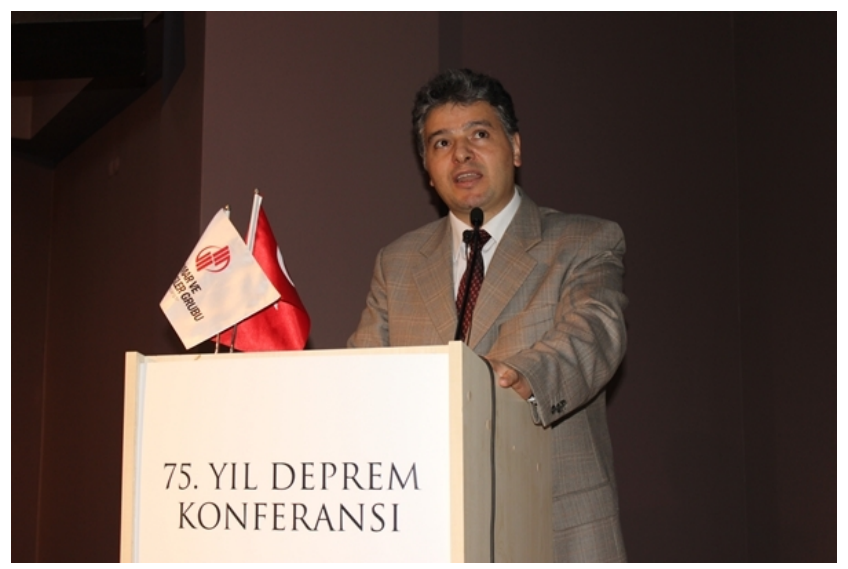

i.Ü.AUZEF Dekan Yardımcısı Prof.Dr. Deniz EKinci sunumunu yaparken.
- 2014 yılı Aralık ayı sonu itibariyle; kurumumuz periyodik yayın organı olan Türk Coğrafya Dergisi 63. Sayısı internet ortamında Doç. Dr. Hasan ÖZDEMiR'in Baş-editörlüğünde yayınlanmıştır (http://www.tcd.org.tr/index.php/tcd).

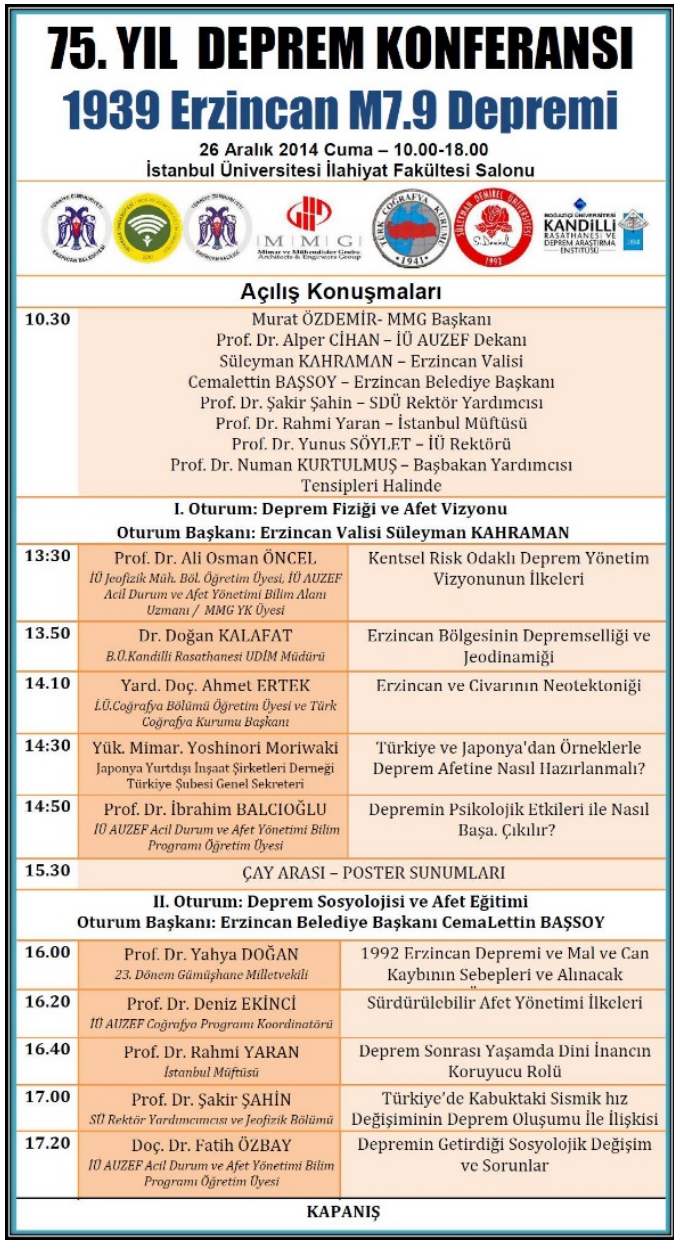

1939 Erzincan Depreminin 75.yılı “Deprem Konferansı” afişi.

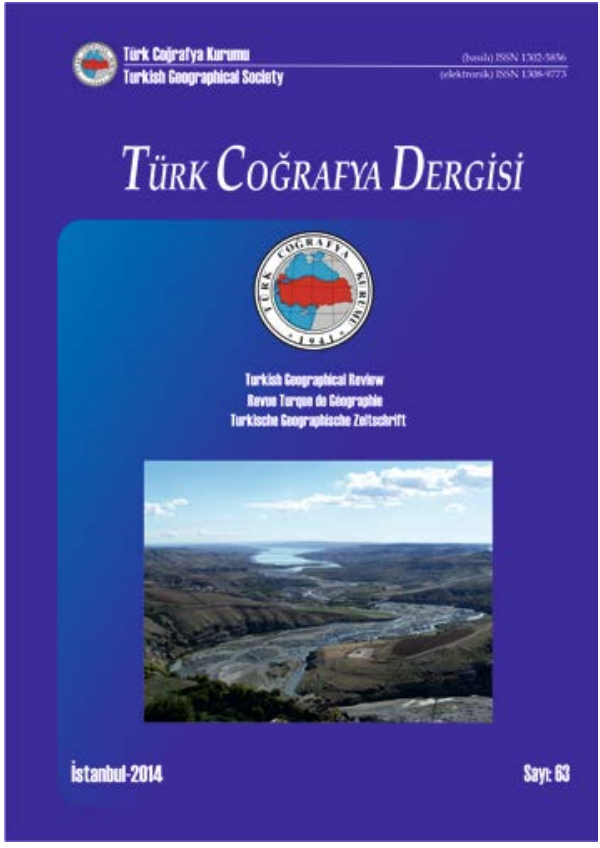

Türk Coğrafya Dergisi Sayı: 63 kapağı (2014). 
- Türk Coğrafya Dergisinin internet sitesi yenilenmiş ve yeni digital ortamda yazarlara, yazı gönderecek yazarlara, hakemlere ve TCK Yazı Kuruluna ulaşmanın posta yolu yerine tamamen digital ortama geçilmiştir. Bu zorlu geçiş; Türk Coğrafya Dergisi Baş-editörü Doç.Dr. Hasan ÖZDEMiR denetiminde ve büyük emekleriyle gerçekleştirilmiştir.

- Türk Coğrafya Dergimizin 1-49. Sayıları arasındakiler sadece kağıt dergi ortamında değil; daha geniş kitlelere ulaşması amacıyla taranarak "Türk Coğrafya Dergileri Arşivi" oluşturulmak suretiyle, dijital ortamına aktarılması tamamlanmış; TCK Başkanı Ahmet ERTEK'in koordinasyonunda gerçekleşen bu zorlu görev sonunda; coğrafyacıların ve kamuoyunun TÜRK COĞRAFYA DERGILERININ tamamını internet ortamında okumaları sağlanmıştır (www.tcd.org.tr).

- 2013'te yenilenen çehresiyle Türk Coğrafya Kurumu internet sitesi (www.tck.org.tr), ayrıca facebook ve twitter hesaplarl; kurumumuz Yönetim Kurulu Üyesi Mesut Süzer'in denetiminde üyelerimizi bilgilendirmek amaçlı internet ortamında yayın hayatını tüm yıl sürdürmüştür.

2014 TCK Faaliyet Raporu saygılarımızla bilgilerinize sunulur (31.12.2014). 


\section{Türk CoĞRAFya Dergisi}

Sayı 63, Aralık 2014

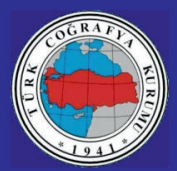

İçindekiler

Editörden

Makaleler

Abdullah AKBAŞ

Türkiye'de klimatik kuraklık olasılıklarının dağılışı

(Distribution of climatological drought probabilities in Turkey).....

İzmit Körfezi kıyılarında kıyı alanı kullanımı

(The usage of coastal area in the coasts of Gulf of Izmit)..

Murat SUNKAR \& Zeynel KARATAȘ

Ahmet ÇAVUȘ

Not

Hasan ÖZDEMIR

\section{Türk Coărafva Kurumu'ndan}

Faaliyet Raporu (1 Ocak-31 Aralık 2014)
Kâhta Çayı Aşağı Havzası'nın (Adıyaman) jeomorfolojik özellikleri

(Teh geomorphological characteristics of lower Kahta Stream basin (Adiyaman)).

Trabzon'da doğa turizmi açısından değerlendirilmesi gereken turistik bir alan: Sera Gölü

(The area required assessment touristy for nature tourism in Trabzon: Sera Lake)

Türk Coğrafya Dergisi'ndeki yayınlar hakkında (1943-2014)

(About the publication of Turkish Geographical Review in between 1943 and 2014). 